\title{
Aplikasi Ujian Online Dengan Metode Exteme Programming Pada MTs AI Muddatsiriyah
}

\author{
Annisa Fitrianti ${ }^{1}$, Kresna Ramanda ${ }^{2}$, Arief Rusman ${ }^{1^{\star}}$ \\ ${ }^{1}$ Sistem Informasi, Sekolah Tinggi Manajemen Informatika dan Komputer Nusa Mandiri, \\ Jakarta, Indonesia email: annisafitrianti700@gmail.com, arief.aef@nusamandiri.ac.id \\ 2 Teknik Informatika, Sekolah Tinggi Manajemen Informatika dan Komputer Nusa Mandiri, \\ Jakarta, Indonesia email: kresna.kra@nusamandiri.ac.id
}

*Korespondensi: email: arief.aef@nusamandiri.ac.id

Diterima: 29 Oktober 2020; Review: 8 November 2020; Disetujui: 13 November 2020;

Cara sitasi: Fitrianti A., Ramanda K, Rusman A. 2020. Aplikasi Ujian Online Dengan Metode Exteme Programming Pada MTs Al Muddatsiriyah. Informatics for Educators and Professionals. 5(1): 43-52.

\begin{abstract}
Abstrak : Sekolah merupakan suatu institusi yang di dalamnya terdapat komponen guru, siswa, dan staf administrasi yang setiap individu mempunyai tugas tertentu dalam menjalankan program. Tidak hanya itu, didalam pelaksanaan kegiatan pembelajaran juga sangat erat kaitannya dengan pelaksanaan sistem ujian. Baik itu berupa ujian tengah semester, hingga ujian akhir sekolah yang juga bertujuan sebagai penilaian seberapa jauh pengetahuan yang sudah diperoleh oleh para siswa. Dalam tahapan proses pengembangan sistem ini, penulis menggunakan metode Agile untuk mengutamakan fleksibelitas terhadap perubahan-perubahan yang terjadi selama pengembangan. Bahkan, kalau pun nantinya masih ada perubahan ataupun penambahan pada saat fase terakhir dapat segera teratasi. Berdasarkan hasil dan pembahasan mengenai Aplikasi Ujian Online, serta wawancara dengan bagian akademik Mts Al Muddatsiriyah. Dapat di simpulkan sistem Rancangan Aplikasi Ujian Berbasis Web ini, dapat menggantikan sistem ujian berbasis kertas dan bisa diakses oleh siswa menggunakan jaringan internet.
\end{abstract}

Kata Kunci : Agile, Aplikasi ujian, Sekolah, Website

\begin{abstract}
School is an institution in which there are components of teachers, students, and administrative staff, each individual has a specific task in carrying out the program. Not only that, in implementing learning activities it is also very closely related to the implementation of the examination system. Whether it's in the form of midterm exams, to school final exams, which also serve as an assessment of how much knowledge the students have acquired. In this stage of the system development process, the authors use the Agile method to prioritize flexibility to changes that occur during development. Even if there are still changes or additions during the last phase, they can be resolved immediately. Based on the results and discussion of the Website-Based Examination Application Design system, as well as interviews with the academic section of Mts Al Muddatsiriyah. It can be concluded that this Web-Based Exam Application Design system can replace the paper-based examination system and can be accessed by participants using the internet network
\end{abstract}

Keywords : Agile, Exam Application, School, Website

\section{Pendahuluan}

Sekolah merupakan suatu institusi yang di dalamnya terdapat komponen guru, siswa, dan staf administrasi yang setiap individu mempunyai tugas tertentu dalam menjalankan 
program [1]. Sebagai institusi pendidikan formal, sekolah dituntut menghasilkan lulusan yang mempunyai kemampuan akademis tertentu, keterampilan, sikap dan mental.

Tidak hanya itu, didalam pelaksanaan kegiatan pembelajaran juga sangat erat kaitannya dengan pelaksanaan sistem ujian. Baik itu berupa ujian tengah semester, hingga ujian akhir sekolah yang juga bertujuan sebagai penilaian seberapa jauh pengetahuan yang sudah diperoleh oleh para siswa. Dalam dunia pendidikan ujian dimaksudkan untuk mengukur taraf pencapaian tujuan pengajaran kepada siswa sebagai peserta didik, sehingga guru dan siswa dapat mengetahui tingkat kemampuannya dalam memahami bidang studi [2].

Ujian konvensional atau ujian manual sudah diterapkan puluhan tahun yang lalu dan masih digunakan saat ini [3]. Ujian jenis ini menggunakan alat tulis sebagai media ujian yaitu berupa kertas, pensil, pena dan alat tulis umum lainnya untuk pelaksanaan ujian. Soal ujian dan jawaban semua dilakukan dengan tulisan tangan.

Seiring dengan berkembangnya teknologi informasi, sistem ujian tertulis bergeser menjadi sistem ujian online berbasis web [4]. Setiap organisasi harus beradaptasi dengan perkembangan teknologi yang semakin canggih, salah satu faktor pendukungnya adalah sistem yang tepat guna [5]. Sistem ujian adalah sebuah sistem terintegrasi, sistem manusia mesin, untuk menyediakan dan mengadakan ujian secara lebih cepat dan efektif sehingga dapat diketahui mutunya. Sistem ini memanfaatkan perangkat keras dan perangkat lunak komputer, prosedur manual, dan basis data [4]. Ujian online berbasis web merupakan ujian yang dilakukan dengan alat bantu komputer dan jaringan untuk mengakses halaman web tertentu, dengan mengisi format ujian yang telah disediakan dan format ujian tersebut biasanya berbentuk pilihan ganda. Bantuan sistem akan dapat mempermudah proses pengolahan data yang efisien dan akurat [6].

Sedangkan, proses yang sampai saat ini berjalan adalah para guru masih membuat soal ujian secara tertulis. Setelah itu mencetak soal tersebut, kemudian menyerahkannya kepada panitia ujian untuk digandakan sesuai dengan jumlah siswa-siswi yang akan mengikuti ujian. Hal ini pun pada akhirnya akan membuat para guru kesulitan dalam memeriksa hasil ujian, karena jumlah siswa yang tidak sedikit dan ini bisa saja berakibat menjadi kegagalan bagi para guru dalam menyampaikan materi pembelajaran. Sehingga, hal ini tidak menutup kemungkinan jika nantinya para guru mulai menyama ratakan kemampunan para siswa dan membuat kecemasan para orang tua terhadap pola belajar anak justru semakin nyata.

Untuk mengantisipasi hal tersebut, penulis pun berupaya membangun aplikasi untuk ujian. Dengan tujuan para guru atau tenaga para pendidik dapat lebih fokus terhadap penyampaian materi hingga membangun karakter para siswa, agar lebih memiliki sikap perduli serta tanggung jawab terdahap kemampuan yang harus mereka peroleh dalam standar mata pelajaran tertentu. Terlebih, komunikasi antara guru dengan siswa pun tetap berjalan dengan baik dan diharapkan siswa dapat tuntas dalam menguasai kompetensi dasar di setiap mata pelajaran. Salah satu cara yang dapat digunakan untuk membuat sistem ujian online berbasis WEB adalah dengan bahasa pemrograman Personal Home Page (PHP). PHP merupakan bahasa pemrograman WEB (Server Side)yang nantinya akan berkomunikasi dengan data base, sehingga data dapat diolah [7].

Dalam aplikasi yang akan di bangun ini, guru dapat mengupload soal-soal ujian dan melihat hasil ujian siswa tanpa perlu memeriksa jawaban yang benar. Para siswa dapat lebih efisien dalam mengerjakan soal-soal ujian dan melihat hasil ujian yang telah dikerjakan.

\section{Metode Penelitian}

UML (Unified Modelling Language), UML adalah Keluarga notasi grafis yang didukung oleh meta-model tunggal, yang membantu pendeskripsian dan desain sistem perangkat lunak khususnya sistem yang dibangun menggunakan pemrograman berorientasi objek [8]. Unified Modeling Language (UML) merupakan bahasa pemodelan yang berbentuk grafis yang digunakan untuk memvisualisasi, menspesifikasikan suatu sistem perangkat lunak [9].

ERD (Entity Relationship Diagram), ERD adalah bentuk paling awal dalam melakukan perancangan basis data relasional. ERD merupakan singkatan dari Entity Relationship Diagram, dikembangkan berdasarkan teori himpunan dalam bidang matematika. ERD digunakan untuk pemodelan basis data relasional. Sehingga jika penyimpanan basis data menggunakan OODBMS (Object Oriented Database Management System) maka perancangan basis data tidak perlu menggunakan ERD. Model ERD terdiri dari beberapa komponen dasar yaitu Entitas, Atribut, Relasi dan Tingkat Hubungan [10]. 
Sistem adalah kumpulan dari elemen-elemen yang berinteraksi untuk mencapai suatu tujuan tertentu[11]. Pendekatan sistem yang merupakan jaringan kerja dari prosedur yang lebih menekankan urutan-urutan operasi. Suatu prosedur adalah suatu urutan-urutan yang tepat dari tahapan-tahapan instruksi yang menerangkan apa (what) yang harus dikerjakan, siapa (who) yang mengerjakan, kapan (when) dikerjakan dan bagaimana (how) mengerjakannya.

Sistem Informasi adalah suatu sistem didalam suatu organisasi yang mempertemukan kebutuhan pengolahan transaksi harian yang mendukung fungsi operasi organisasi yang bersifat manajerial dengan kegiatan strategi dari suatu organisasi untuk dapat menyediakan kepada pihak luar tertentu dengan laporan-laporan yang diperlukan [11]. Sistem informasi telah diterapkan dalam berbagai bidang, seperti penerapan sistem informasi pada bidang transportasi, pendidikan, proyek, kesehatan, dan bidang-bidang lainnya [12]. Fokus penelitian ini pada bidang pendidikan.

Agile Software Development, proses ini ditandai dengan model yang dikenal dengan interaktif dan inkremental. Proses yang meyakini bahwa suatu perangkat lunak dapat dikembangkan dengan desain minimalis, pengujian bertahap, dan dokumentasi yang tidak berlebihan[13]. Adapun beberapa tahapannya adalah planning, design, coding dan testing [8].

Extreme Programming, dikenal dengan metode technical how to atau bagaimana suatu tim teknis mengembangkan perangkat lunak secara efisien melalui berbagai prinsip dan teknik praktis pengembangan perangkat lunak. XP menjadi dasar bagaimana tim bekerja sehari-hari [14].

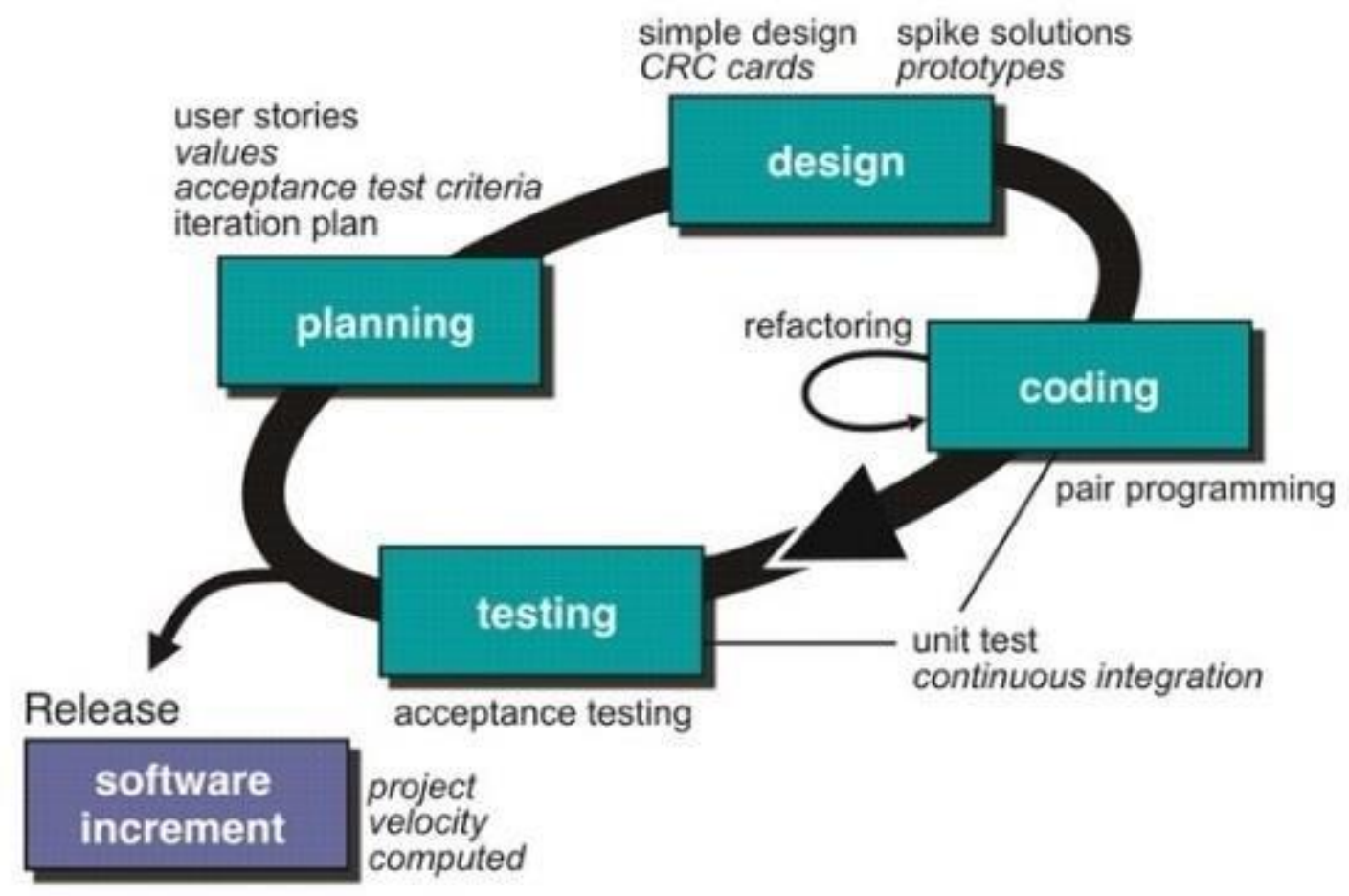

Sumber : [14]

Gambar 1. Tahapan Penelitian Model Xtreme Progamming

Tahap Planning, Planning yaitu Tahap planning dimulai dengan membuat user stories yang menggambarkan output, fitur, dan fungsi-fungsi dari software yang akan dibuat. User stories tersebut kemudian diberikan bobot seperti prioritas dan dikelompokkan untuk selanjutnya dilakukan proses delivery secara incremental.

Tahap Design, Design pada Extreme Programming mengikuti prinsip Keep It Simple (KIS). Untuk design yang sulit, Extreme Programming akan menggunaan Spike Solution dimana pembuatan design dibuat langsung ke tujuannya. Extreme Programming juga mendukung adanya refactoring dimana software system diubah sedemikian rupa dengan cara mengubah stuktur kode dan menyederhanakannya namun hasil dari kode tidak berubah.

Tahap Coding, Proses coding pada XP diawali dengan membangun serangkaian unit test. Setelah itu pengembang akan berfokus untuk mengimplementasikannya. Dalam Extreme 
Programming diperkenalkan istilah Pair Programming dimana proses penulisan program dilakukan secara berpasangan. Dua orang programmer saling bekerjasama di satu komputer untuk menulis program. Dengan melakukan ini akan didapat real-time problem solving dan realtime quality assurance.

Tahap Testing, Tahap ini dilakukan pengujian kode pada unit test. Dalam Extreme Programming, diperkenalkan XP acceptance test atau biasa disebut customer test. Tes ini dilakukan oleh customer yang berfokus kepada fitur dan fungsi sistem secara keseluruhan. Acceptance test ini berasal dari user stories yang telah diimplementasikan.

\section{Hasil dan Pembahasan}

Tahap Planning, pada tahapan analisis aplikasi ujian online pada MTs AI Muddatsiriyah ini, admin dan user melakukan pengelolaan data seperti pengelolaan data guru, data siswa, data mata pelajaran, data ujian, cetak kartu ujian dan cetak hasil nilai ujian.

Tahap Design, pada tahapan ini akan dilakukan proses rancangan desain dimulai dari pemodelan data, class diagram, sequence diagram dan component diagram. Pada gambar 2 menampilkan pemodelan data menggunakan Logical Data Model yang akan diterapkan pada aplikasi ujian online.

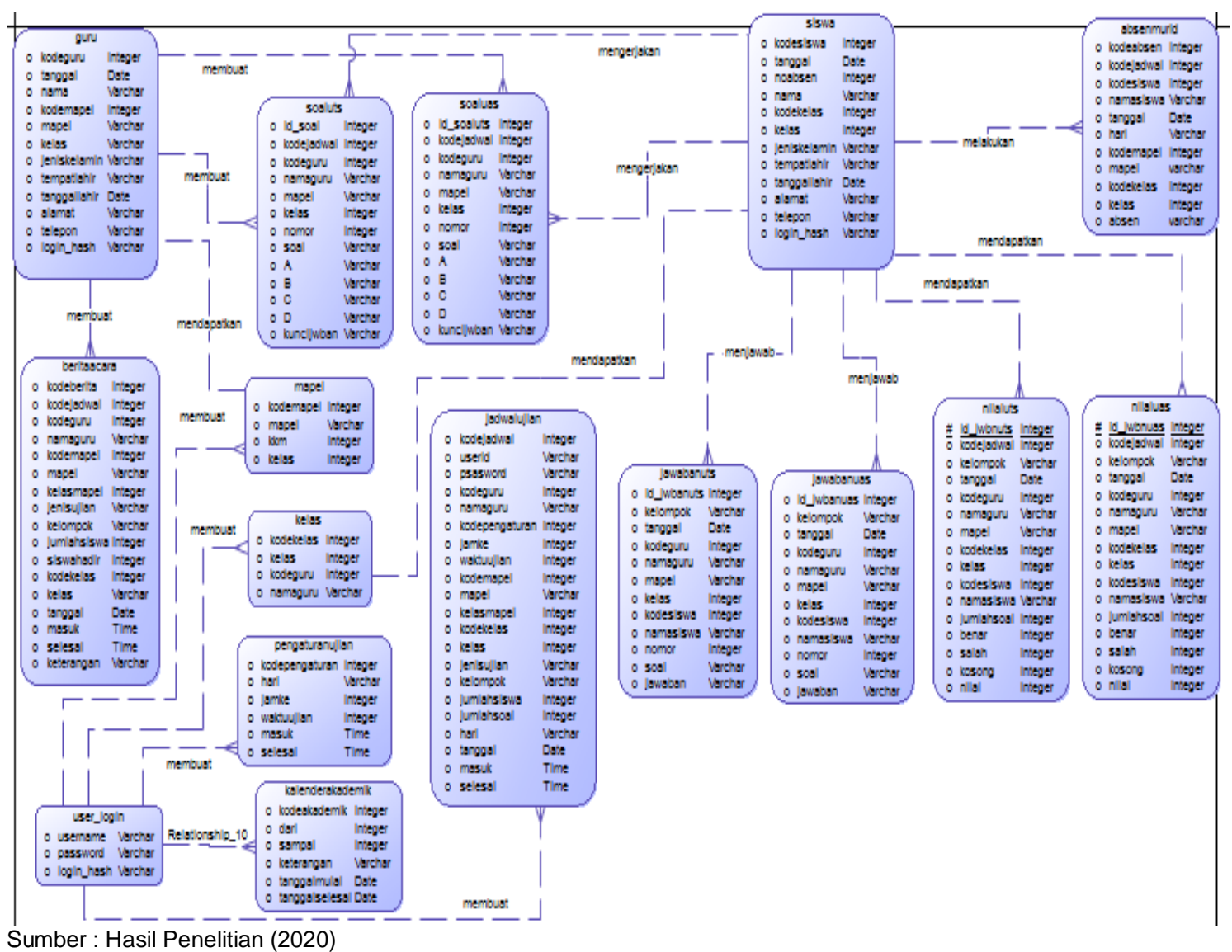

Gambar 2. Logical Data Model Aplikasi Ujian Online

Setelah pemodelan logik, maka selanjutnya dikonversi menjadi Physical Data Model yang digambarkan pada gambar 3 berikut ini. 


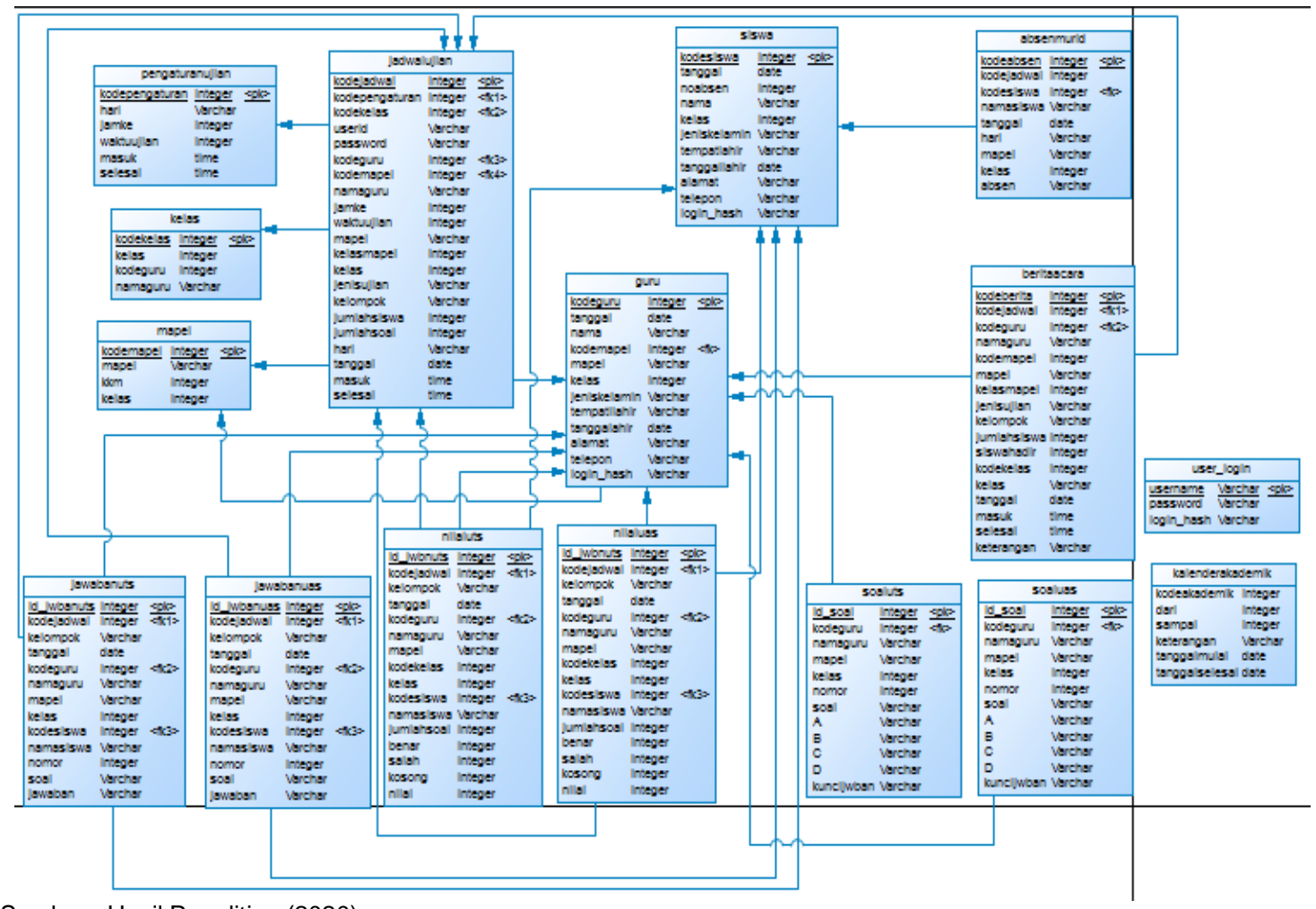

Sumber : Hasil Penelitian (2020)

Gambar 3. Physical Data Model Aplikasi Ujian Online

Untuk pemodelan kelas-kelas yang dikelola dalam aplikasi ujian online akan digambarkan mengggunakan class diagram pada gambar 4 berikut ini.

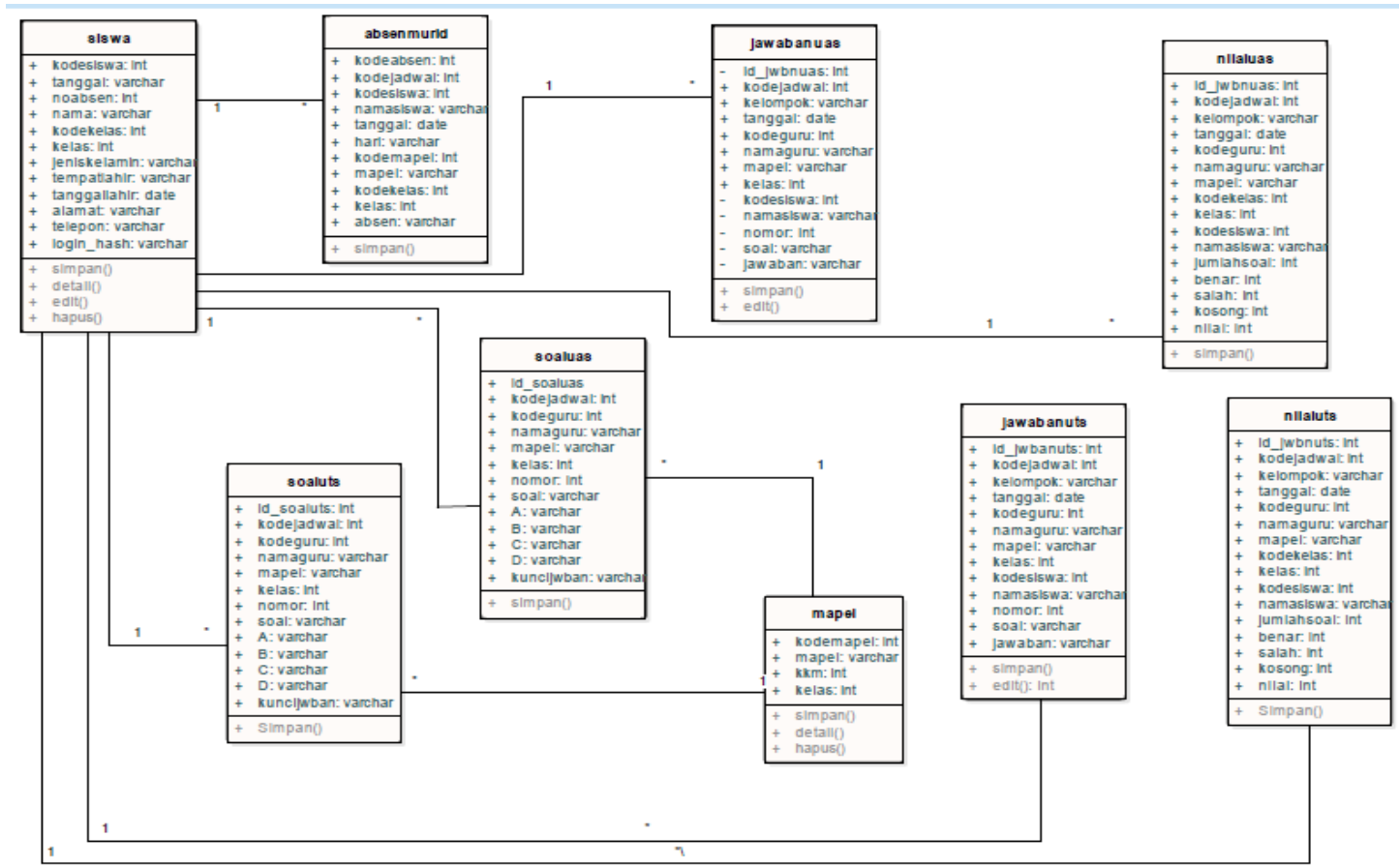

Sumber : Hasil Penelitian (2020)

Gambar 4. Class Diagram Aplikasi Ujian Online berikut ini.

Desain rancangan selanjutnya yaitu sequence diagram yang ada pada gambar 5 


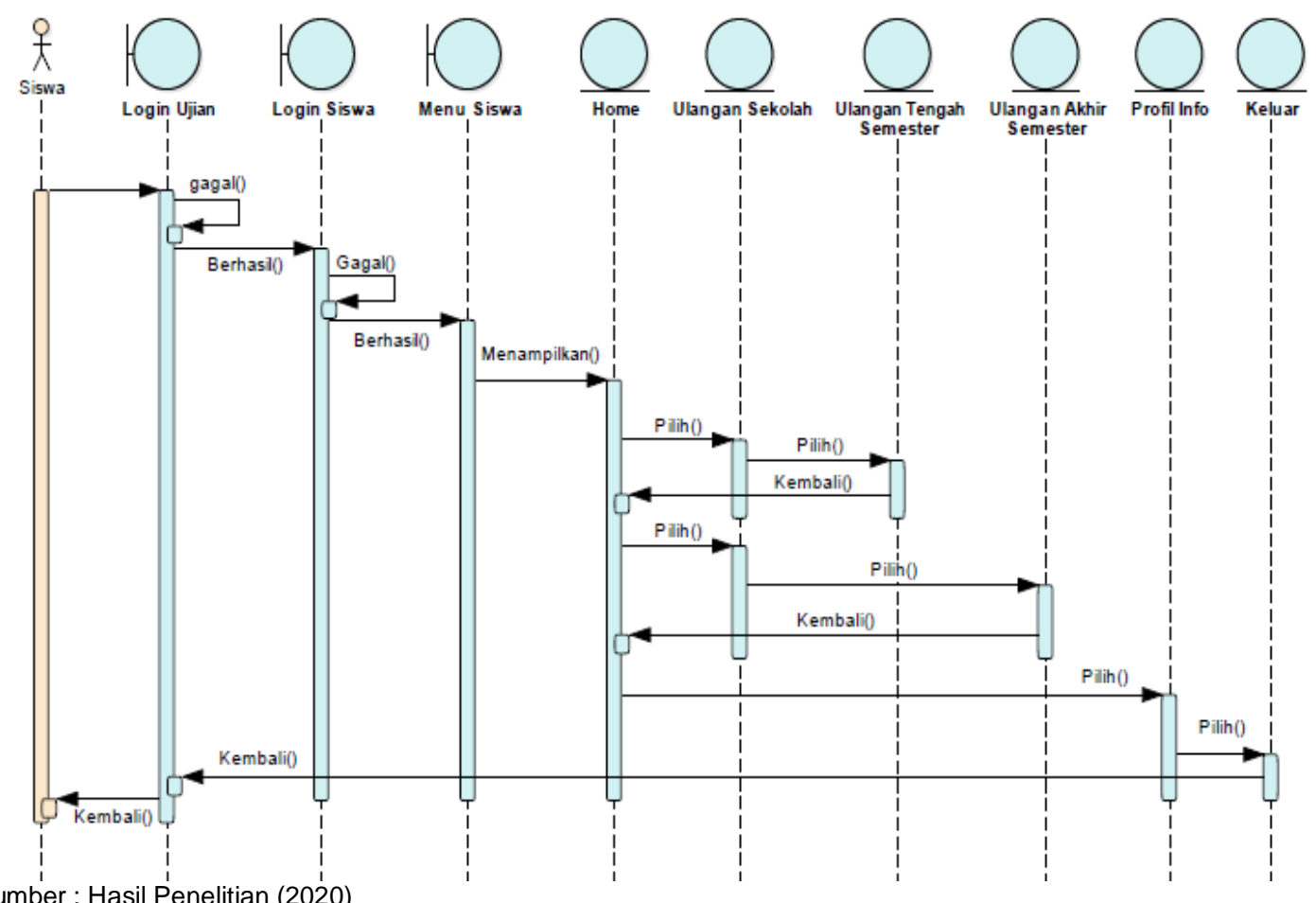

Gambar 5. Sequence Diagram Aplikasi Ujian Online

Componen diagram aplikasi ujian online digambarka pada gambar 6 berikut ini yang terdapat 6 komponen pedukung dari komponen utama pada aplikasi.

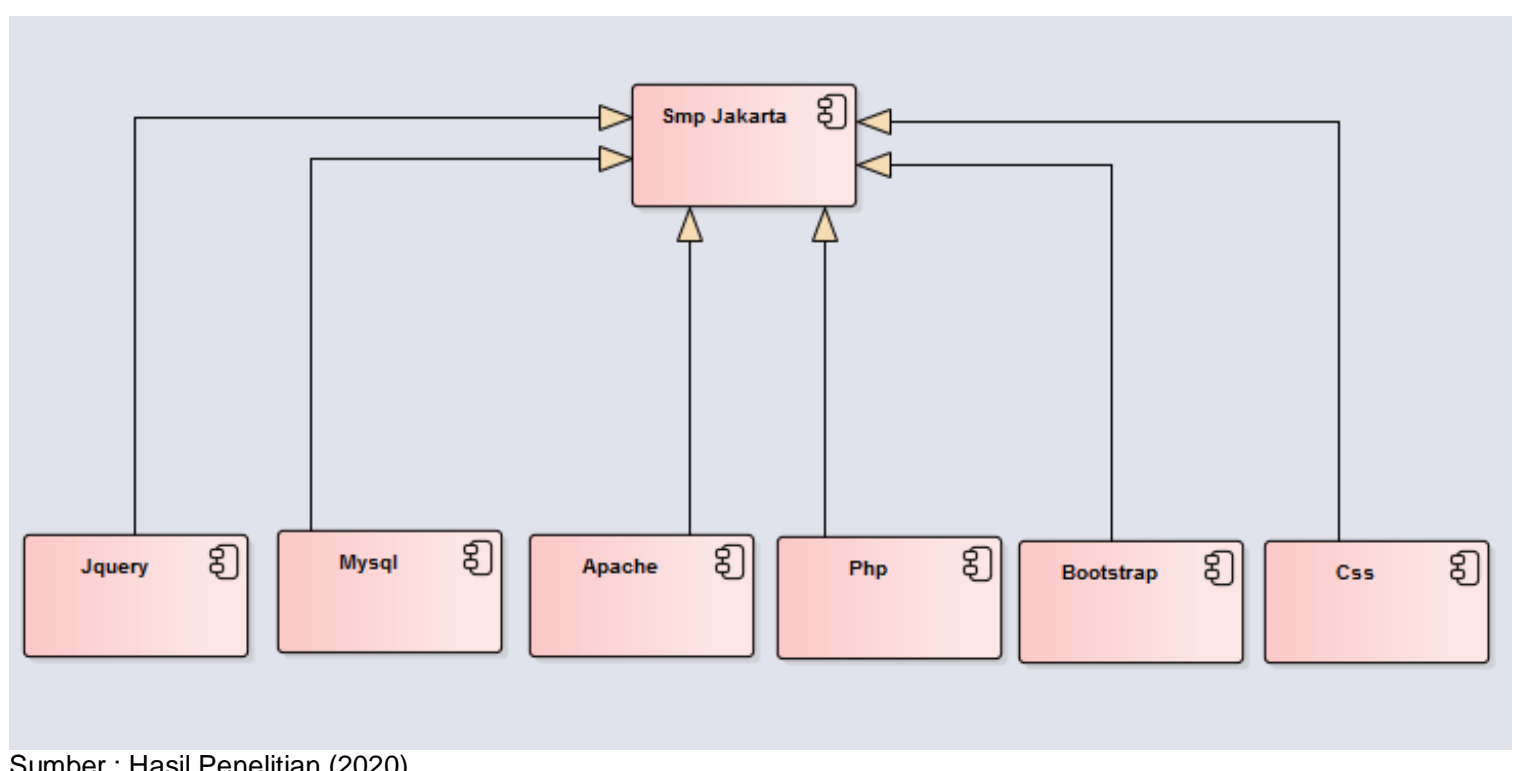

Gambar 6. Component Diagram Aplikasi Ujian Online

Tahap Coding, implementasi desain ke bentuk coding antar muka aplikasi ujian online Pada Mts Al Muddatsiriyah ini dibagi menjadi beberapa halaman dengan masing-masing fungsinya dapat dilihat pada tabel 1 berikut ini. 
Tabel 1. Halaman Aplikasi Ujian Online

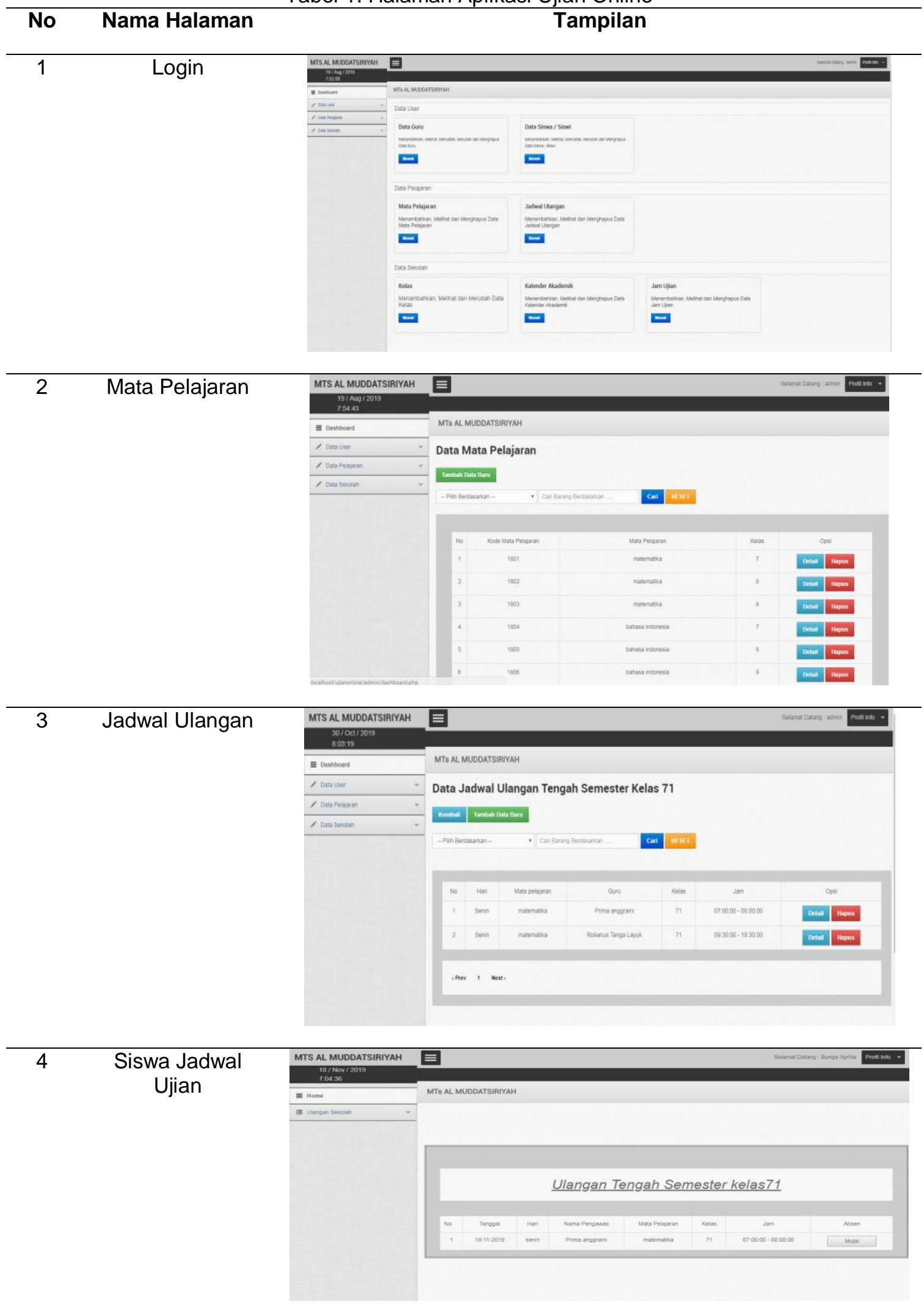




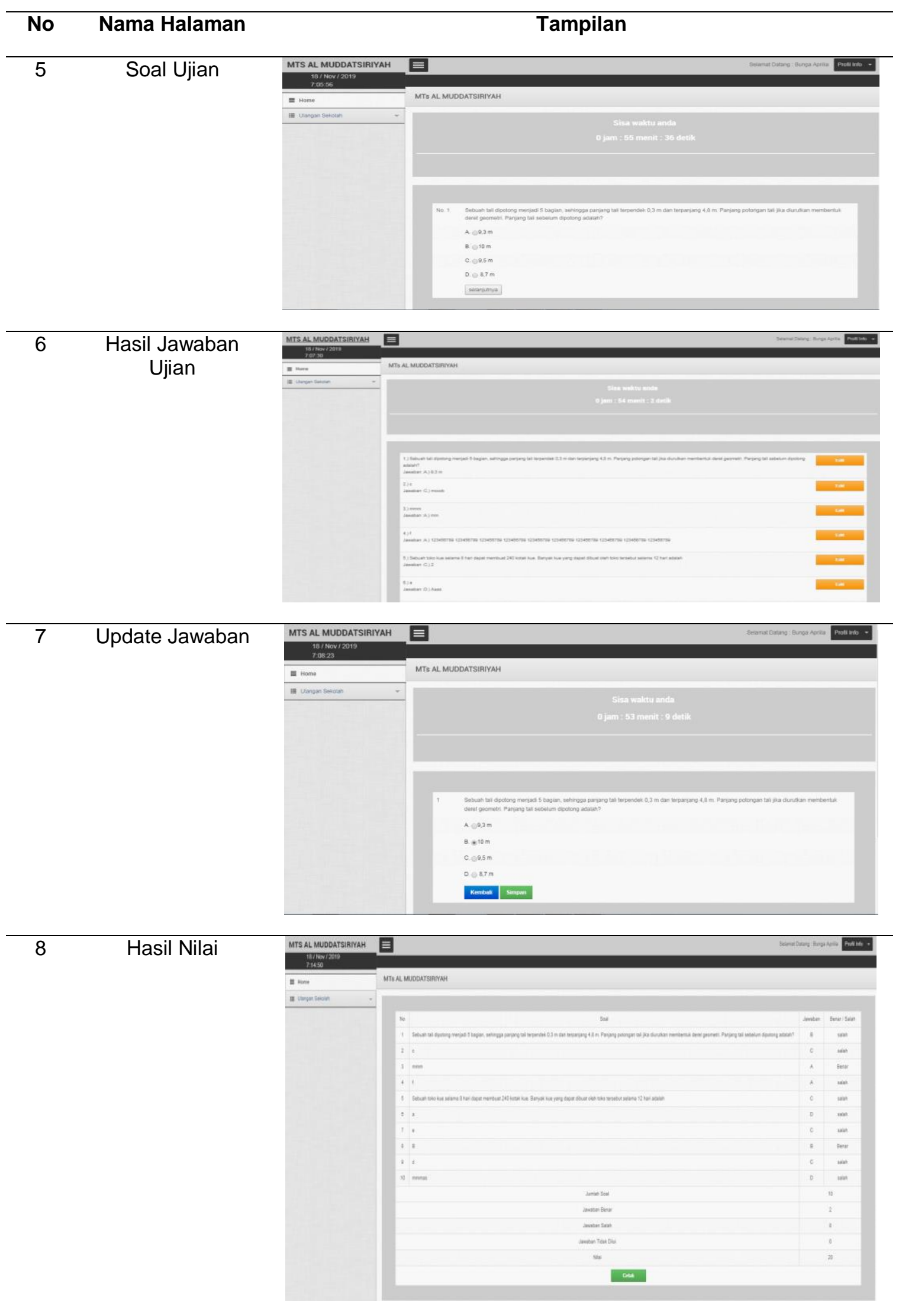


E-ISSN: 2548-3412; $43-52$

Berdasarkan tabel 1, dapat dilihat bahwa halaman aplikasi memiliki banyak fitur utama mengenai pelaksanaan ujian online. Pertama yaitu halaman login yang digunakan semua pengguna untuk masuk kedalam aplikasi ujian online. Kedua yaitu halaman mata pelajaran yang akan menampilkan mata pelajaran apa saja yang akan diujiankan. Ketiga yaitu halaman jadwal ulangan yang akan menampilkan informasi jadwal ujian secara keseluruhan pada aplikasi. Keempat halaman siswa jadwal ujian yaitu akan menampilkan jadwal ujian per siswa ujian. Kelima yaitu halaman soal ujian, dimana informasi mengenai soal-soal ujian akan ditampilkan pada halaman tersebut. Keenam yaitu halaman hasil ujian, halaman ini menampilkan informasi mengenai hasil ujian dari seluruh siswa yang mengikuti ujian. Ketujuh yaitu halaman update jawaban, pada bagian ini akan muncul fungsi untuk melakukan perubahan jawaban ujian. Halaman kedelapan yaitu halaman hasil nilai, yang akan menampilkan hasil dari nilai-nilai yang diperoleh oleh para siswa yang mengikuti ujian online.

\section{Kesimpulan}

Berdasarkan hasil dan pembahasan mengenai aplikasi ujian online serta wawancara dengan bagian akademik Mts Al Muddatsiriyah, dapat di simpulkan sebagai berikut : a). Sistem rancangan aplikasi ujian berbasis web ini, dapat menggantikan sistem ujian berbasis kertas dan bisa diakses oleh peserta menggunakan jaringan internet. b) Sistem rancangan aplikasi ujian berbasis web ini, dapat meringankan tugas guru dalam pembuatan soal-soal ujian dan juga penilaian hasil ujian siswa.

Sebaik apapun sistem yang dibuat pasti memiliki kekurangan yang perlu untuk dikembangkan, yaitu dengan membuat versi terbaru dari sistem tersebut. Untuk itu dibuatlah penyampaian dalam bentuk saran untuk kesempurnaan sistem ini di masa mendatang. Adapun saran tersebut yaitu, aplikasi ujian online pada Mts Al Muddatsiriyah ini hanya memiliki jenis soal pilihan ganda yang dilengkapi dengan jawaban dari bank soal. Pada penelitian selanjutnya, diharapkan memiliki jenis soal lain seperti jawaban singkat atau soal menjodohkan dengan disertai pengacakan dari bank soal.

\section{Referensi}

[1] A. Wijaya and F. Fransisca, "Try Out Simulation Test Untuk Persiapan Siswa Menghadapi Ujian," J. Bus. Audit Inf. Syst., vol. 1, no. 2, pp. 47-55, 2018.

[2] S. Susilowati and T. Hidayat, "Rancang Bangun Sistem Informasi Ujian Online ( Studi Kasus Pada SMAN 58 Jakarta )," J. Tek. Komput., vol. 4, no. 1, p. 7, 2018.

[3] M. R. Sampebua and S. B. Membala, "Penerapan Aplikasi Ujian Berbasis Komputer Untuk Meningkatkan Kualitas Pendidikan Pada Smp," J. Pengabdi. Papua, vol. 2, no. 1, pp. 24-31, 2018.

[4] R. Sonjaya, A. Sumiah, and D. Nugraha, "SISTEM INFORMASI UJIAN SEKOLAH ONLINE BERBASIS DATA WAREHOUSE (STUDY KASUS: SMP NEGERI 2 LURAGUNG)," J. Nuansa Inform., vol. 11, no. 1, pp. 43-52, 2016.

[5] N. Safitri and R. Pramudita, "Sistem Informasi Pelayanan Pengobatan di Puskesmas," vol. 2, no. 2, pp. 181-194, 2018.

[6] R. Pramudita and N. Safitri, "Sistem Informasi Pemantauan Kegiatan Bimbingan Calon Jamaah Haji," vol. 2, no. 2, pp. 169-178, 2018.

[7] D. Satria and L. Wati, "Perancangan Ujian Online Menggunakan Model Computer Based AssesmentBerbasis Client-Server (Studi Kasus: SMA PGRI Kota Payakumbuh)," INOVTEK Polbeng - Seri Inform., vol. 1, no. 1, p. 57, 2016.

[8] M. Fowler, UML Distilled 3th Panduan Singkat Bahasa Pemodelan Berorientasi Objek Standar. Yogyakarta: Andi Ofset, 2005.

[9] Y. Heriyanto, "Perancangan Sistem Informasi Rental Mobil Berbasis Web Pada PT.APM Rent Car," J. Intra-Tech, vol. 2, no. 2, pp. 64-77, 2018.

[10] R. A. Sukamto and M. Shalahuddin, Rekayasa perangkat lunak terstruktur dan berorientasi objek. Bandung: Informatika, 2013.

[11] T. Sutabri, Analisa Sistem Informasi. Yogyakarta: Andi, 2012.

[12] N. Safitri, "Model Kesuksesan Sistem Teknologi Informasi Delone \& McLean pada Sistem Informasi Pengelolaan Proyek," vol. 4, no. 2, pp. 173-182, 2020.

[13] R. Ferdiana, Rekayasa Perangkat Lunak yang Dinamis dengan Global Extreme Programming. Yogyakarta: Andi, 2012. 
[14] R. S. Pressman and B. Maxim, Software Engineering: A Practitioner's Approach. New York: McGraw-Hill Education, 2014. 